\title{
Anseio impronunciável: Alejo Carpentier, ficção histórica e os escritos sapienciais
}

\section{Unpronounceable yearning: Alejo Carpentier, historical fiction and wisdom writings}

Eduardo Ferraz Felippe ${ }^{1}$

\section{Resumo}

Ao enfatizar a leitura de dois romances de Alejo Carpentier, El reino de este mundo (1949) e Los pasos perdidos (1953), privilegio a recepção dos escritos sapienciais com o intuito de entender a valorização de uma ética e modos de perceber o futuro. Ao mesmo tempo, analiso o contraste, em sua obra, entre sabedoria e conhecimento como forma de destacar o temário do aprimoramento humano. Por fim, este ensaio joga luz sobre o tema da insubmissa relação entre texto e contexto por meio de uma operação formal.

Palavras-chave: Alejo Carpentier; ética; Antigo Testamento; futuro.

\begin{abstract}
At emphasizing the reading with El reino de este mundo (1949) and Los pasos perdidos (1953), I priorize the reception of the wisdom writings in order to understand the ethic valorization and the perception of future. At the same time, there is a contrast, in his work, the divergence between wisdom and knowledge in the writing. Finally, this essay gives light to the insubordinate relation between text and context given by the valorization of a formal operation.
\end{abstract}

Keywords: Alejo Carpentier; ethics; Sacred Scripture; future.

Artigo recebido em: 31/08/2014

Artigo aprovado para publicação em: 26/11/2014
Acabamos de chegar e não sabemos como foi. Não nos pergunteis de onde vimos: basta-vos saber que aqui estamos.
Goethe.

Uma leitura contemporânea da obra de Carpentier se encontra no palco em que um regime historiográfico procura se desfazer de sua máscara, perguntando por si mesmo, buscando a si mesmo, apresentando seu próprio jogo. Às claras, representa uma tendência que possui marcos importantes, não somente na história literária, mas também

1 Professor de História da Universidade do Estado do Rio de Janeiro (UERJ). E-mail: ffeduerj@gmail.com

\section{CANPHLAC}

Revista Eletrônica da ANPHLAC, ISSN 1679-1061, Nº. 17, p. 1-5, jul./dez. 2014. http://revista.anphlac.org.br/ 
na tendência atual da historiografia de adquirir uma aguda consciência de si própria para se apresentar enquanto tal, para denunciar suas próprias convenções, para indagar acerca de seu próprio regime discursivo. Um percurso permissivo a modos plurais de representação do passado em sua manifestação enquanto discurso histórico, especialmente por meio de operações formais. Considerando tais questões, este ensaio apresenta um autor a criar seu próprio protocolo de leitura e a sugerir delineamentos da relação com o passado a partir da ênfase em uma sabedoria prática. Proveniente do contato com os escritos sapienciais, o destaque recai em enredos cujos temas do aprimoramento humano e do autoconhecimento são destacáveis. A princípio, permitenos debater algumas das afinidades eletivas entre História e Romance pela atenção ao valor do texto e suas figuras de linguagem (LACAPRA, 1985), mesmo que, para Carpentier (1975), nossa época manifestasse a decadência do romance.

Para os rumos deste escrito, a relação entre texto e contexto, na história intelectual, não deve ser entendida de forma separada. Justamente o que pondera Dominick LaCapra (1983): uma história intelectual como uma história de textos atenta aos diversos narrares da experiência humana em uma dada historicidade. Evitam-se, dessa maneira, as crenças comuns de oposição entre texto e realidade, que simplesmente não se sustentam, pois “o passado nos chega através de e em forma de textos e remanescentes textualizados" (LACAPRA, 1983, p. 128). Investe-se, principalmente, contra as dualidades presentes na história intelectual como texto/contexto, para que, dessa forma, tenha-se clareza de que ao passado somente se pode reportar "através de um artefato que é textual por natureza" (WHITE, 1992, p. 138).

Ao transformar o enquadramento da questão, percebe-se um panorama novo, rascunhado por uma das principais marcas da obra do autor cubano: a presença de uma indagação mística a manifestar dilemas de ordem intelectual. Assim, o lance de luz deixa na penumbra alguns temas mais debatidos ao colocar ao centro o que também interessa ao romancista, um enigma existencial associado ao aperfeiçoamento humano. Esse conjunto de temas era parte de sua busca na tradição, assim como a intenção de encontrar o artístico ao longo dos tempos, manifestado sob a forma do literário, como no artigo "América ante la joven literatura europea". O ato de indagar, em uma obra dessa envergadura, possibilita que se fuja das leituras tendo ao centro o conceito de

\section{GANPHLAC}

Revista Eletrônica da ANPHLAC, ISSN 1679-1061, Nº. 17, p. 1-5, jul./dez. 2014. http://revista.anphlac.org.br/ 
maravilhoso, como bem executado por Leonardo Padura Fuentes em Un camino de medio siglo: Alejo Carpentier y la narrativa de lo real maravilloso. Assim, o que se apresenta são outras possibilidades de conexão em sua fortuna crítica. Milan Kundera, em A cortina, propõe uma associação pouco comum: considera que Herman Broch inaugurou a integração de diversas épocas históricas em uma só composição, caminho seguido por Carpentier. Ao associar Os sonâmbulos, de Herman Broch, à pergunta: "Por que a Europa deve morrer?”, destina à obra de Carpentier outra pergunta, essa típica da América: "Por que tivemos de nascer?” (KUNDERA, 2006, p. 149).

A resposta a tudo isso não pode ser encontrada de forma plena. Pelo contrário, ela se situa em um território híbrido, nunca plenamente classificado, sem que se torne apreensível ao todo. A seleção de alguns escritos produzidos entre os anos de 1948 e 1959 define um perfil de autor anterior às palestras em que valoriza o engajamento político, como em Tientos y diferencias e a Literatura do maravilhoso. Sua obra exprime-se, dessa forma, por meio da tensão entre experimentalismo artístico e engajamento político, especialmente no período anterior à Revolução Cubana. Trata-se da conjunção de dois livros, El reino de este mundo (1949) e Los pasos perdidos (1953), como a fatia mais fértil de uma obra apreendida por meio da amplitude de alguns conceitos a ela alocados, seja pelo autor, seja por seus comentaristas. "Real maravilhoso" e "barroco" são os dois mais conhecidos a sugerir essa circunstância de apreensão da obra como totalidade unificada.

Esses conceitos, tomados como desígnio de toda a obra, são, na verdade, a apreensão de um instante particular vinculado ao fechamento das proposições políticas que marcaram o contexto cultural após a Revolução Cubana - disparador da vontade de politização do intelectual e da expectativa revolucionária ${ }^{2}$ (GILMAN, 2003). O engajamento político de alguns escritores levou ao anseio pelo acontecimento Revolução (RODRIGUES, 2002) e os direcionou a uma determinada perspectiva de entendimento de escrita, de história e de passado. Pelo fato de os relatos de Carpentier terem uma ancoragem histórica definível, por vezes foram lidos por meio da imediatez

\footnotetext{
${ }^{2}$ Em termos de políticas culturais, por exemplo, havia diferença que se estabelecia através da defesa buscada por Casa de las Américas de um latino-americanismo que divergia frente à perspectiva mais abrangente proposta pela revista Mundo Nuevo, em que havia a intenção de inserir a cultura latinoamericana como parte literária do Ocidente (MOREJÓN ARNAIZ, 2010).
}

\section{CANPHLAC}

Revista Eletrônica da ANPHLAC, ISSN 1679-1061, Nº. 17, p. 1-5, jul./dez. 2014. http://revista.anphlac.org.br/ 
com que atribuía aos enredos uma externalidade de significado. El reino de este mundo (1949) recebeu a definição de romance histórico voltado a contar a Revolução do Haiti; em nota similar, El siglo de las luces (1962) foi considerado como um romance histórico cuja intenção é apontar “ecos” da Revolução Francesa no Caribe.

Este ensaio propõe um diálogo aberto e plural entre dois livros de Carpentier com leituras do monoteísmo e sua ulterior secularização. Por vezes distanciadas, por outras em íntima conexão, trechos diversos foram incorporados dentro da narrativa de suas ficções históricas como expressão de força estética e cognitiva. A ênfase em determinadas passagens do Antigo Testamento - com predileção pelos livros poéticos e os escritos sapienciais -, algumas citações da $\mathrm{Kabbalah}^{3}$ e enredos em que a finitude humana é sublinhada sugerem algumas questões contemporâneas referentes à historiografia. Suas ficções históricas podem ser entendidas por meio da diferença citada por Hayden White entre a política da interpretação e "aquelas práticas interpretativas que têm a própria política como objeto específico de interesse" (WHITE, 1992, p. 75). O mesmo autor lembra que, antes da disciplinarização da história, Aristóteles havia proposto a complementaridade entre história e poesia como forma de representar a totalidade do mundo (WHITE, 2005, p. 147). Não obstante, ainda é White a enfatizar que a distinção entre História e Literatura não deve ser feita por meio de valores associados ao que é falso, mas pelo repensar das relações entre a verdade, uma preocupação da História, e o real, uma preocupação da ficção.

Grande parte da fortuna crítica que se deteve nas ficções históricas aqui selecionadas colocou em seu centro interpretativo a questão da América Latina como eixo de compreensão dos textos. ${ }^{4}$ A predileção por passagens do Antigo Testamento auxiliam a entender a crítica ao realismo histórico, como em "Problemática do atual romance latino-americano", sem que haja o imediato vínculo às narrativas da América Latina. $\mathrm{O}$ relato passa a ter uma atenção maior às variações dos personagens e, em seus

\footnotetext{
${ }^{3}$ Especificamente acerca da Kabbalah, pouco foi dito pela fortuna crítica. Há apenas um curto embate entre Roberto González Echevarría (1977), ao afirmar a presença da Kaballah em El siglo de las luces (1962), e Steven Hanley, em Explosion in a Cathedral: Gnostic Archetypes in a Lukácsian Historical Novel, ao enfatizar, em toda a obra, o gnosticismo como uma negociação com o materialismo histórico.

${ }^{4}$ Há deslocamentos variáveis, mas ainda tendo como centro a América Latina. Um exemplo de estudo bem desenvolvido acerca do tema pode ser encontrado em PALMERO GONZÁLEZ, Elena (Org.). No reino de Alejo Carpentier: doze ensaios críticos. Rio Grande: Editora FURG, 2009.
}$$
\text { CANPHLAC }
$$

Revista Eletrônica da ANPHLAC, ISSN 1679-1061, Nº. 17, p. 1-5, jul./dez. 2014. http://revista.anphlac.org.br/ 
escritos, há uma dimensão exemplar de transmissão de significados após a meditação das ações concretas da vida. Sendo assim, há dois eixos de análise intimamente imbricados dispostos neste ensaio. O primeiro, a escrita de ficções históricas, permite uma mirada particular acerca da narrativa latino-americana e sua relação com a historicidade; em um segundo instante, lançar luz aos escritos sapienciais permite entender ênfases da obra, como a homogeneidade do drama humano, a ressignificação dissonante com a tradição religiosa e a aproximação entre eventos originários e acontecimentos cotidianos. Por fim, sua obra se insere em uma tradição de leitura que não é apenas da América Latina. O sábio ensinamento de aceitar os limites humanos enquanto parte acabada e reconhecível da nossa condição.

\section{Ausência de sentido e a tarefa humana}

El reino de este mundo narra as aventuras de Ti Noel por meio de uma obra de ficção, tendo a Revolução Haitiana como pano de fundo. Há uma tensão entre o tempo da narrativa coletiva, a Revolução Haitiana, e o instante da conexão com a narrativa individual, com os acontecimentos da vida de Ti Noel. Sua ficção histórica pode ser bem associada à tradição do romance histórico, por exemplo. Há a princípio uma perspectiva de entendimento do que se considera verdade histórica:

Por que es menester advertir que el relato que va a leerse ha sido establecido sobre una documentación extremadamente rigurosa que no solamente respeta la verdad histórica de los acontecimientos, los nombres de personajes". (CARPENTIER, 1949, p. 8)

Há um sentido específico de que a verdade histórica é projetada sobre um senso de respeito à veracidade demonstrada nos documentos procurados particularmente pelo autor em arquivos. Essa opção projeta um sentido de verdade associado ao estudo e decifração hermenêutica do sentido das fontes históricas utilizadas pelo autor.

Em El reino de este mundo (1949), há o investimento na valorização de uma determinada postura. A composição de enredos diversos entre si, como em El reino de este mundo ou Los pasos perdidos, propiciam a escrita do passado latino-americano ancorado em características de exemplaridade, ao vinculá-la a passagens do Antigo

\section{GANPHLAC}

Revista Eletrônica da ANPHLAC, ISSN 1679-1061, №. 17, p. 1-5, jul./dez. 2014. http://revista.anphlac.org.br/ 
Testamento. Texto ainda associado, por um lado, ao romance histórico de proveniência de Walter Scott, por outro lado, sugere novos encaminhamentos para o que depois ficou conhecido como o boom literário latino-americano, como a noção de "realismo maravilhoso". A tensão entre colonos negros e brancos, base do enredo do romance, propicia ao autor mesclar diversas influências voltadas à melhor compreensão da narrativa que se desenvolve em capítulos iniciados na revolta até a instalação da República.

Especialmente a partir dos capítulos finais do relato, o cenário de ruínas passa a tomar conta de todo o texto. A princípio Roma, depois as ruínas do Palácio Sans-Souci. O contraste das civilizações é uma característica de Carpentier. Não obstante, o que mais interessa à proposta que o leitor tem em mãos é o comentário de que a "tarea del hombre", citada tanto em El reino de este mundo quanto em Los pasos perdidos, é a expressão da força humana e de um instante de epifania em que a vida ganha sentido. A viagem de retorno de Ti Noel delimita a aceitação da carga hercúlea de um "cansancio cósmico, de planeta cargado de piedras" sobre seus ombros "descarnados por tantos golpes, sudores y rebeldías" (CARPENTIER, 1949, p. 110-109). Ao fim, a narrativa se encaminha para um instante de fechamento:

\footnotetext{
Querer mejorar lo que es; en imponerse tareas. En el reino de los cielos no hay grandeza que conquistar, puesto que allá todo es jerarquia establecida, incógnita despejada, existir sin término, imposibilidad de sacrifício, reposo y deleite. Por ello, agobiado de penas y tareas, hermoso dentro de su miséria, capaz de amar en medio a las plagas, el hombre sólo puede hallar su grandeza, su máxima medida en el reino de este mundo. (CARPENTIER, 1949, p. 110)
}

Mais do que uma bela cena, o curto trecho evoca relações, instala comparações e motiva o comentário. A miséria do homem é a condição da sua beleza. Em meio ao reino deste mundo, aquilo que lhe resta, diante da radical assincronia com os deuses, é obter o refrigério momentâneo de construir para si um caminho que lhe possibilite "mejorar" através da imposição de "tareas". Falar de sua grandeza e receber o referido reconhecimento por isso somente ocorre por meio de uma opção desconhecida dos deuses: a imposição de sacrifícios, a escolha de atitudes na vida prática e uma modelagem humana. Em termos de enredo, há a opção pela vinculação entre destino e

\section{CANPHLAC}

Revista Eletrônica da ANPHLAC, ISSN 1679-1061, Nº. 17, p. 1-5, jul./dez. 2014. http://revista.anphlac.org.br/ 
totalidade, o que relembra traços da epopeia como marca de sua escrita. A escrita fragmentada, como afirma Anke Birkenmaier (2006, p. 216-229), é uma das marcas destacáveis de El reino de este mundo. Por meio do diálogo com a Antropologia, a autora realça as experiências radiofônicas de Carpentier como auxílio na construção da "oralidad mediatizada" como marca da sua poética.

Essa operação formal, contudo, não deixou de associá-lo ao temário antigo do aperfeiçoamento humano por meio da escolha por uma vivência assentada em valores estáveis que o unem a uma tradição letrada universal. Carpentier parece sugerir uma ética que parte de uma estética. Uma espécie de "estética da existência" (FOUCAULT, 1985), cuja referência provém de suas leituras da Antiguidade ${ }^{5}$ e está vocacionada ao refino de si em meio ao turbilhão do mundo. El oficio del hombre é uma forma de decifração de si consigo com o intuito de uma atuação orientada no mundo. A medida de si advém do reino deste mundo. Carpentier reveste seu vocabulário de um sentido caro à tradição da Antiguidade: o lapidário de si ou a vida como obra de arte. Trata-se da composição de um estilo admirável de vida, como no caso do romance El reino de este mundo. Suas amplas leituras da tradição clássica, manifestadas pela presença de citações de autores como Epicuro e Epiteto, por textos como "La elaboración de Ulises" ou "Semejante a la noche", originalmente publicado na revista Orígenes, permitem atrelar seus escritos ao estoicismo de autores que associam sua estadia no mundo à busca da composição de uma vida na qual não se submetam a uma verdade, mas se transformem a partir dela. Abre-se, assim, espaço para uma ética da existência como o cuidado de si que terminaria por entrelaçar, de modo indissolúvel, o autorreconhecimento e a carência de sentido.

Carpentier leu os autores da Antiguidade, especialmente Epiteto (LÓPEZ CALAHORRO, 2006), e atualiza seus escritos por fundamentar seus romances em uma ética, como forma permanente da busca pela liberdade do homem das formas de dominação - como no caso do personagem central de El reino de este mundo - e o permanente anseio pela composição de uma obra de arte em suas ficções. Cabe a lembrança de Michel Foucault (1984; 1985), ao considerar que a ética do cuidado de si

\footnotetext{
${ }^{5} \mathrm{O}$ conjunto de suas leituras e a proximidade com as leituras da Antiguidade estão descritas em Chao (1985).
}

\section{CANPHLAC}

Revista Eletrônica da ANPHLAC, ISSN 1679-1061, №. 17, p. 1-5, jul./dez. 2014. http://revista.anphlac.org.br/ 
romano e helenístico, apreciada por Alejo Carpentier, é fundamentalmente imanente, associando-o à distância e vigilância, não como conhecimento de si, mas como cuidado. O efeito é um personagem principal cuja particularidade é uma ética do sujeito como estética da existência que dispensa o compromisso com valores universais. O efeito é um governo de si mesmo, um controle da conduta que não nega a intervenção no mundo.

Apesar de escrever tendo como matriz o passado, seu horizonte de possibilidades o atrelam ao presente, porém sem ainda rascunhar o futuro. Retoma, assim, princípios greco-romanos em que o sujeito é um objeto a dar-se a conhecer por meio de práticas que permitem a moldagem de si. El oficio del hombre para aqueles que buscam abertura e crescimento. A produção de Carpentier, durante as décadas de 1940 e 1950, anteriores à adesão ao regime cubano revolucionário, representa a ligação estreita com uma concepção valorosa da existência humana, alicerçada na "mejora" constante por meio do desenvolvimento de sua capacidade reflexiva e do controle dos instintos. $E l$ reino de este mundo traz um amplo manancial de relações íntimas tecidas entre a produção do romance e a escolha pelas leituras de uma determinada tradição clássica (LÓPEZ CALAHORRO, 2006).

A partir do estudo da autora, opto por deslocar suas proposições para valorizar a centralidade do aprimoramento humano como eixo de sua obra. A aparição do mito de Sísifo ${ }^{6}$ em seus textos, durante essas duas décadas, pode ser o indicativo da busca de sua obra. "Padece y espera y trabaja para gentes que nunca conocerá, y que a su vez padecerán y esperarán y trabajarán para otros que tampoco serán felices..." (CARPENTIER, 1949, p. 110). O trecho sugere a circularidade de um trabalho que jamais encontra seu fim, nem mesmo que seus olhos vejam o findar da sua própria geração. O tempo do homem está em diferença radical frente ao tempo da história, o reconhecimento entre o homem e seu sentido não alcançam plena certeza. “... el hombre ansia siempre una felicidad situada más allá de la porción que le es otorgada" (CARPENTIER, 1949, p. 110). Sugere refinamento de si e ampliação da existência por

\footnotetext{
${ }^{6} \mathrm{O}$ vínculo entre obra e morte pode ser destacado, em seus escritos, pela presença do mito de Sísifo. Valoriza-se a astúcia no embate entre o humano e o divino. A ressignificação do mito é sugerida por meio de suas leituras de Camus (Le Mythe de Sisyphe, 1942) e da escrita de Diario intimo de Kafka (CARPENTIER, 1951), em que há menção ao mito.
}

\section{CANPHLAC}

Revista Eletrônica da ANPHLAC, ISSN 1679-1061, №. 17, p. 1-5, jul./dez. 2014. http://revista.anphlac.org.br/ 
meio das obras. A vida somente ganha orientação por meio da imputação de sentido dada pela confecção das obras.

A articulação com a leitura da Bíblia pode encaminhar algumas reflexões de modo um pouco diverso. O narrador bíblico, o Eloísta, em sua busca pela verdade, não exatamente pela "realidade", como percebe Eric Auerbach, fez com que a intenção religiosa condicionasse a exigência de verdade histórica gerando a estreita relação entre historicidade e mobilidade social. No Antigo Testamento, o problemático, o sublime e o trágico se formam no cotidiano e exacerbam o cunho individual do relato, em comparação com a Odisseia. A partir dessa perspectiva, pode-se entender como a grandeza do humilhado se aproxima do sobre-humano em similaridade à grandeza divina (AUERBACH, 1976, p. 11-16). El reino de este mundo apresenta menções a Salmos. Coletânea de poemas mais cantados da Bíblia, o título em hebraico, Tehillim "louvores" - (SELLIER, 2011, p. 129), é mais preciso. Os Salmos apresentam variações em interpretações alegóricas, como acontece no 90, por exemplo, que, afinado ao Eclesiastes, lamenta a fugacidade da vida face à eternidade, assim como a inconstância das coisas humanas. O Capítulo $\mathrm{V}$ de El reino de este mundo tem como título De Profundis, associação ao Salmo $130 \mathrm{em}$ seu tom de canto à miséria humana, somente redimida pelo esforço na construção das obras.

\section{Decadência e escrita}

Los pasos perdidos (1953) elabora uma narrativa em forma de diário em que o narrador, inominado, reinterpreta seu cotidiano na paisagem selvática latino-americana em busca de distanciar-se de um cotidiano europeu sem sentido. ${ }^{7}$ Após uma penosa viagem, o protagonista chega a Santa Monica de los Venados, povoado fundado pelo Adelantado, um de seus companheiros de viagem. Santa Monica não é mais do que um clarão na selva, na qual o protagonista, distanciado da Europa, busca reavivar suas energias inventivas, voltar à sua vida de compositor, e tem em mente compor um poema musical baseado na Odisseia. Ao chegar ao povoado, pede ao Adelantado um novo

\footnotetext{
${ }^{7}$ Esse livro foi, em geral, associado ao tema das viagens, a uma experiência vivenciada em meio à natureza, o que o aproximaria de Henry Miller (MELO, 2010). Esse tema continuou vivo em sua escrita, mesmo que articulasse diversos motivos para a permanência da andança em outros livros, como El arpa y la sombra (1978) (PALMERO GONZÁLEZ, 2008).
}

\section{CANPHLAC}

Revista Eletrônica da ANPHLAC, ISSN 1679-1061, Nº. 17, p. 1-5, jul./dez. 2014. http://revista.anphlac.org.br/ 
pedaço de papel no qual pudesse escrever, logo depois pede outro, e recebe o aviso de que será o último. Obriga-se a escrever com letra muito pequena - borra, apaga e reescreve. Sempre. Um percurso de perdas, ganhos e rascunhos escritos e apagados. Uma imagem que lida com o passado latino-americano em uma textualidade própria a ecoar em toda a trajetória de escritos do continente, com movimentos de aproximação e distanciamento. O texto remonta ao início dessa inscrição como parte de um presente vazio, que joga luzes e sombras para o futuro e o passado. A ficção histórica de Carpentier descapacita a existência de um Novo Mundo, liberado da história, como presente em outras narrativas que percebem a América como pura.

Roberto González Echevarría (2000, p. 26) definiu Los pasos perdidos como um instante de mutação na história da narrativa latino-americana, a fundação do que chamou de "ficção arquivista". A partir dela, e com reverberação em Vargas Llosa, Garcia Márquez e Carlos Fuentes, essas ficções passaram a conter potencialidades narrativas que dialogavam com uma tradição pautada, a princípio, no discurso jurídico, durante o período colonial; da ciência, no século XIX; e da antropologia, já no século XX. Los pasos perdidos e Cien años de soledad representam instantes fundamentais dessa tradição narrativa, já que não a reitera nem a abandona. Relaciona-se com ela por meio da figura do arquivo - uma metáfora para o conhecimento como espaço em que é possível trocar e mudar de forma múltipla até atingir um sentido particular. Uma pista para essa perspectiva é a noção de verdade histórica apresentada pelo autor em Los pasos perdidos.

Nos instantes finais de Los pasos perdidos, o autor reflete acerca da caracterização de seus personagens, apresentando um ponto de vista diferente do que havia sido proposto em El reino de este mundo.

El Adelantado, Montsalvaje, Marcos, Frey Pedro, son os personagens que encontra todo viajero en el gran teatro de la selva. Responde todos a una realidad, como responde a una realidad también, un cierto mito del Dorado, que alientan todavía los yacimientos de oro y de pedras preciosas. En cuanto a Yannes, el minero griego que viajaba con el tomo de La Odisea, por todo haber, baste decir que el autor no ha modificado su nombre, siquiera. (CARPENTIER, 1953, p. 224)

\section{CANPHLAC}

Revista Eletrônica da ANPHLAC, ISSN 1679-1061, №. 17, p. 1-5, jul./dez. 2014. http://revista.anphlac.org.br/ 
Sua narração é tanto uma forma que apresenta uma interpretação histórica quanto um tipo de discurso em que se exibe uma compreensão efetiva da leitura documental. Explicita, assim, uma associação entre interpretação, narração e compreensão que, diferente de relatos como La consagración de la primavera, aproximavam-se mais da caracterização de romance histórico típico do século XIX, com sua proposição realista. Já em Los pasos perdidos, Carpentier indica que houve a subordinação da sua imaginação, como é típica dos estudos históricos, às regras de evidência. Essas regras "exigen que todo lo que se imagina sea congruente con lo que la evidencia permite afirmar como "cuestión de hecho" (WHITE, 1992, p. 85). Sua análise aproxima-se daquilo que Peter Gay (2006) entende como o "estilo do historiador": a utilização da imaginação como uma etapa posterior ao exame das fontes quando é necessário compor um discurso ou uma narrativa dotada de sentido.

No caso de Los pasos perdidos, os personagens parecem ter certa sensação de esgotamento com a Europa dita "civilizada". Existem algumas cenas em que o mundo europeu, exaurido da possibilidade de dar significado à vida dos homens, é contrastado à emergência do novo, a América. A dimensão da viagem se apoia nessa opção, quando afirma que "el mundo mediterráneo" é "una paisaje en ruinas" (CARPENTIER, 1953, p. 163). A Europa ruinosa que acordava do pesadelo da Guerra é deixada para trás. Contudo, sua escrita não delata somente a decadência europeia, mas busca reencontrar um lugar, e não uma identidade para a América entendida como outra, impensável. Dessa maneira, a América não é a alternativa confiável, como alguns críticos consideram, em contraposição à Europa; pelo contrário, ela apela para uma contra leitura que, digamos, fuja da montagem do próprio excesso do maravilhoso, presente em romance anterior, El reino de este mundo.

A montagem básica do enredo se dá pelo contraste entre ação humana e destino. Há a presença destacável da cultura greco-latina, como a análise de Klaus Müller Berg (1972) ao enfatizar a importância da Odisseia como um diálogo de Los pasos perdidos. O personagem Ulisses representa uma figura de ação que rompe com a circularidade de mitos e consegue, através de sua viagem, representar um homem novo, capaz de, pela astúcia, suplantar o herói trágico, submetido ao destino. "En una escuelita de Kalamata les enseñaron los nombres de los trágicos y el sentido de los mitos, pero una oscura

\section{GANPHLAC}

Revista Eletrônica da ANPHLAC, ISSN 1679-1061, Nº. 17, p. 1-5, jul./dez. 2014. http://revista.anphlac.org.br/ 
afinidad de caracteres los acercó al aventurero Ulises... capaz de ignorar a las sirenas por no perder su hacienda de Itaca" (CARPENTIER, 1953, p. 167). Inserir Ulisses em sua escrita implica distinguir entre o homem submetido ao Destino, o herói, e o homem cujas desgraças advêm de suas ações no mundo por sua "tontería" - geralmente identificados com uma vivência na cidade sem sentido do qual a selva é o encontro com forças primitivas (ADAMS, 1975; GROTTO, 2009). Diante das variações da ordem do mundo e da potência do destino, a ação humana segue seu percurso ao agenciar os obstáculos desse mesmo mundo em um palco como uma selva

Sobre el destino de su pueblo, abre el tomo en su comienzo y clama: “¡Ah, miseria! Escuchad cómo los mortales enjuician a los dioses. Dicen que de nosotros vienen sus males, cuando son ellos quienes, por su tontería, agravan a las desdichas que les asigna el destino." (CARPENTIER, 1953, p. 113)

Todo esse artifício da escrita é feito com o intuito de, por meio do contraste, destacar os limites e as possibilidades do homem contemporâneo, imerso em sua "tontería". Ao mesmo tempo, trata-se de refletir acerca do lugar e do papel da América no mundo, após toda a destruição causada pela Segunda Guerra Mundial. Presente e passado, ontem e hoje, (re)encontro consigo mesmo numa espécie de caminhada a utilizar o tempo como sintoma daquele que não se resolve na circularidade de suas ações. Há uma estratégia retórica de atar um movimento através do espaço a outro movimento, o que o leva a experienciar tempos pretéritos, seja a Gran Savana, seja o Orinoco. Temporalidades múltiplas vocacionadas ao elementar desejo humano de um pórtico seguro.

Em Los pasos perdidos, esse despojo ganha vida e passa a estar na boca do protagonista, ao comentar alguns artistas na América.

El tema era uno sólo: Paris. Y yo observaba ahora que estos jóvenes interrogaban a mí amiga como los cristianos del Medioevo podían interrogar al peregrino que regresaba de los Santos Lugares... La cultura - afirmaba el pintor negro - no estaba en la selva. Según el músico, el artista de hoy sólo podía vivir donde el pensamiento y la creación estuvieran más activas en el presente, regresándose a la ciudad cuya topografía intelectual estaba en la mente de sus compañeros... Los veía yo enflaquecer y empalidecer en sus estudios sin lumbre - ...

\section{CANPHLAC}

Revista Eletrônica da ANPHLAC, ISSN 1679-1061, Nº. 17, p. 1-5, jul./dez. 2014. http://revista.anphlac.org.br/ 
regresarían a sus países con la mirada vacía, los arrestos quebrados, sin ánimo para emprender la única tarea que me pareciera oportuna en el medio que ahora me iba revelando lentamente la índole de sus valores: la tarea de Adán poniendo nombre a las cosas. (CARPENTIER, 1953, p. 75)

O recurso ao Gênesis, destacável ao longo de todo o livro, novamente ganha forma. No caso de Los pasos perdidos, a noção do encontro com o Éden remete a certo passado inaugural, em que a natureza desempenha papel destacável, em que o mito adâmico é o elemento primordial. Entretanto, cabe observar que há sutilezas nos argumentos de Carpentier. A problemática da designação está em Los pasos perdidos como um ato que busca criar menções para a América, o que a retira de seu lugar de virgindade. O poder de designação que vincula Adão ao Novo Mundo é o mesmo ato que atrela o escritor ao mundo das palavras. Os escritos de Carpentier tendem ao inventivo desejo de a linguagem articular a inadequação existencial entre o dizível e o visível. A descrição minuciosa dos lugares percorridos pelo protagonista em Los pasos perdidos sugere uma relação de conveniência que pode ser rompida e rearticulada pelos homens. A relação de parecença entre as coisas deflagra a gritante aparência, conjunção de potência e engano que nunca propicia uma resposta final. "Lo que más me asombraba era el inacabable mimetismo de la naturaleza. Aquí, todo parecía otra cosa, creándose un mundo de apariencias que ocultaba la realidad, poniendo muchas verdades en entredicho" (CARPENTIER, 1953, p. 133). A mobilização da teoria adâmica sugere a potência humana residindo no reino da linguagem, ao mesmo tempo em que, articulada ao escrito, solicita a correspondência, falaciosa diríamos, entre mundo e expressão. Se as verdades estão postas em "entredicho", nada de seguro permanece no ar ou no terreno movediço a percorrer. Toda nomeação é, no fundo, decepção: "La selva era el mundo de la mentira, de la trampa, del falso semblante: allí todo era disfraz, estratagema, juego de apariencias, metamorfoses" (CARPENTIER, 1953, p. 161).

Adão põe nome, mas, por fim, não chega a nenhum pórtico estável, simplesmente a "juego de apariencias". Em Los pasos perdidos, após citar o Gênesis, considera que as coisas imitam-se, tornando o ambiente de sua escrita falacioso, sem a segurança possível da credulidade de habitar uma terra virgem prestes a imediatamente nomear. Seu escrito é uma alegoria de um mundo em extravio que possui uma herança,

\section{GANPHLAC}

Revista Eletrônica da ANPHLAC, ISSN 1679-1061, Nº. 17, p. 1-5, jul./dez. 2014. http://revista.anphlac.org.br/ 
mas que a vive como um processo permanente de declinação. Esse legado deve ser compreendido como um ponto de acolhimento e endereçamento de uma escrita ficcional que marca a irresolução acerca da descontinuidade e continuidade de categorias como literatura, filosofia, história, artes, América, natureza e homem. Apontar Los pasos perdidos enquanto narrativa a exaltar a ruptura com o passado, como se fosse a exaltação dos primeiros dias da Criação, parece infundado. Los pasos perdidos, justamente por lidar com o novo, guarda grande sentido do tempo.

Los pasos perdidos permite uma remissão analógica. Perda deixa de ser simplesmente associada a uma noção primeva de insucesso e privação, ao passo que esboça o conhecimento associado à ideia de declínio. A América sugere uma experiência individual de descobrimento que vincula a noção de conhecimento como desvio; frente à sua impossibilidade de sucesso há um mundo a nomear, como Adão “poniendo nombre a las cosas”. Assim, perda sugere mudança de rota, flexão, guinada e decaimento. Um modo de incorporar o legado como forma de endereçamento. A inviabilidade de dizer o que é a América oferece sugestões extemporâneas para o acontecimento da escrita. Dessa forma, a América apenas existe em decorrência da imputação de sentido do nome; Adão, ao apontar o dedo para nomear algum espaço, aqui, Santa Monica de los Venados, em outro instante, Macondo, como Garcia Márquez em Cien años de soledad, afirma que a América, e sua adjetivação como nova, existe por meio dessa atribuição de significado. Palavras que vigoram apenas no porvir de suas linhas, como fragmento ou genealogia dispersa de um eco de uma existência humana de tempos primevos, mas que necessita adquirir o chão adiante no alojamento de um cenário. A imagem de um homem que caminha em uma terra distante, que nomeamos América, mas poderia ser qualquer outro território afundado em sombras, como o narrador de Los pasos perdidos, é análoga à de Saul, ao caminhar no deserto em busca do que imediatamente não vê. Deixa, assim, aberta a possibilidade de que o novo seja encontrado sem ocorrer o apagamento do inefável.

\section{Inefável e obscuro}

A predileção por passagens do Antigo Testamento, as referências à Kabbalah e a seleção de autores citados em suas palestras (Shakespeare, Montaigne, Dante, Goethe)

\section{CANPHLAC}

Revista Eletrônica da ANPHLAC, ISSN 1679-1061, Nº. 17, p. 1-5, jul./dez. 2014. http://revista.anphlac.org.br/ 
inserem Carpentier em temário pouco comentado em sua fortuna crítica. Possibilitam algumas associações que, vistas de modo específico, deslocam sua rápida vinculação ao conceito de engajamento político, e, vistas de modo abrangente, o inserem em uma busca por fazer parte de uma linhagem dedicada aos escritos sapienciais. Em termos de regime historiográfico, o que se percebe é o deslocamento de uma perspectiva analítica que se aproxima mais das leituras associadas ao novo historicismo para a possibilidade de uma análise voltada à Teoria Literária e à História Intelectual, atenta às variações do texto.

Carpentier não possuía vinculação religiosa; como escritor, torce, contorce e distorce os escritos sapienciais com leituras a questionar a dimensão teológica do texto. Nenhuma menção ao Novo Testamento há. Percebe-se o autor cubano a olhar para toda a tradição literária e atuar como um alogos, um leitor a surpreender nos textos pessoas e não teorias sistemáticas, seja de sua relação com o passado, seja da composição de seus personagens. Não se trata, caro leitor, de uma predileção por escritos dedicados ao conhecimento de uma determinada parcela do mundo, seja pelo recurso à Ciência, seja pela procura por um término para a busca humana. Talvez por isso Los pasos perdidos termine em páginas a demandar lentidão e ausência de fechamento. Não se trata de privação, que pouco se adequa ao sentido que propomos para Perdidos, mas de limite e possibilidade. América, ou vida, não poderiam ser mais do que suscetíveis ao que se apresenta como intangível e inatingível pelo conhecimento herdado. O mundo é inabordável, como se o protagonista de Los pasos perdidos fosse o primeiro ou o último dos homens. A América Latina de Carpentier deixa a modernidade como quadro aberto e sugere que nossa vivência sem fundamento é um crepúsculo que quer amanhecer.

A insistência de Carpentier na presença do passado e sua crítica da tradição expressam a contemporaneidade de Los pasos perdidos por meio da negação do preexistente, ou seja, do historicismo que pudesse determinar o que é a América Latina. Assim, tensiona os limites da representação histórica ao propor uma narrativização que nega a representação e propõe uma apresentação do passado em que sua tradição de leitura é incorporada por meio de uma radical atenção ao presente, cônscia daquilo que busca e daquilo que incorpora. A citação de Goethe, utilizada como epígrafe para este ensaio - "Acabamos de chegar e não sabemos como foi..." (CARPENTIER, 1975) -,

\section{RANPHLAC}

Revista Eletrônica da ANPHLAC, ISSN 1679-1061, Nº. 17, p. 1-5, jul./dez. 2014. http://revista.anphlac.org.br/ 
situa sua busca como cônscia de uma tradição letrada valorizadora da sabedoria. A pista mais óbvia deixada pelo autor, com relação à Kabbalah, foi a citação inicial do livro $E l$ siglo de las luces proveniente do Zohar: "As sementes não caem no vazio" (CARPENTIER, 1962). O Zohar é a obra central da Kabbalah e defende a noção de que existe um Deus transcendente incognoscível ao homem, a tentar entender sua manifestação sem conseguir plenamente. No sentido literal, Kabbalah significa "receber", o que a relaciona ao desejo de plenitude humana por meio da mística. Além das inúmeras passagens do Antigo Testamento, presente também em Los pasos perdidos, a Kabbalah é apreendida por meio da conjunção entre a mística e a busca por uma ação terrena a utilizar seus ensinamentos como orientação para a ação prática enquanto forma de aprimoramento sensório.

Tanto Los pasos perdidos quanto El reino de este mundo enfatizam o temário da decadência humana. Em Los pasos perdidos, a palavra sugere uma descoberta que não é a verdade, mas obscuridade da qual apreensão alguma é possível de modo completo. Ao longo de todo o livro, de modo diferente a El reino de este mundo, há um bloqueio de futuro, o que está intimamente ligado ao modo como são recepcionados os escritos judaicos em sua obra. Há um anseio silencioso, cuja determinação é empobrecimento e fraqueza ante ao representável. Há um privilégio, nos dois livros de Carpentier aqui analisados, por um determinado conjunto de leituras que valorizam, sobremaneira, os escritos sapienciais do Antigo Testamento.

Utilizando metáforas e marcados pela linguagem poética, esses escritos são construídos como ensinamentos que almejam encontrar a sabedoria. Os "Livros poéticos e sapienciais", conforme nome da Bíblia Grega, englobam os livros de Jó, Provérbios, Eclesiastes, Lamentações, Salmos e Cântico dos Cânticos, presentes desde a Bíblia hebraica (SELLIER, 2011). Essa é uma marca dispersa em toda a obra de Carpentier, estando presente, por exemplo, em diversos instantes, como na abertura do livro Concierto barroco, com a citação do Salmo 81 (CARPENTIER, 2008, p. 7). Os escritos da sapiência, Provérbios e Eclesiastes, assinalam o instante em que a esperança, como marca textual bíblica, vagueia com a poesia em um vazio cosmológico insistentemente reconhecível por meio dos choques entre o sentido e a verdade.

\section{CANPHLAC}

Revista Eletrônica da ANPHLAC, ISSN 1679-1061, Nº. 17, p. 1-5, jul./dez. 2014. http://revista.anphlac.org.br/ 
Em suas ficções históricas, Carpentier utiliza os "Livros poéticos e da sabedoria" como forma de dotar de amplitude de significado seus personagens. A sabedoria, como herdada das passagens bíblicas que seleciona, não significa acumulação de conhecimento ou erudição livresca moderna, mas discernimento mundano. A capacidade discriminativa vem a serviço de um bem viver por meio da forma poética retirada dos escritos sapienciais. A experiência é o lugar da manifestação do divino, a apresentação de um caminho possível para a concretização cônscia das ações na vida diária. As questões fundamentais para Carpentier, desse modo, não se referem a um tema epistemológico da relação entre sujeito e objeto. Vistas pelo prisma de sua associação ao temário dos escritos sapienciais, elas tratam da relação entre o Uno e o Múltiplo em busca de uma parcela possível de reconciliação e de plenitude humanas.

A apropriação de leitura de Carpentier dos escritos sapienciais sugere temas de sua relação com o passado. A presença bíblica em seus textos representou a busca por deglutir a totalidade da herança da literatura latina ocidental, especialmente por meio da valorização da tópica da Falsa Modéstia. Ernst Robert Curtius, lido por Carpentier e Lezama Lima, destaca que há a conjunção entre fórmulas de submissão e protestos de incapacidade com pedidos de sabedoria, especialmente no capítulo IX da Sabedoria de Salomão, no Antigo Testamento (CURTIUS, 2013 [1948], p. 125). Na Vulgata há uma oração que implora a luz da sabedoria. "Oração do sábio em que reconhece a própria debilidade mental para obter do senhor a sabedoria" (CURTIUS, 2013 [1948], p. 125).

A força de outro escrito sapiencial, como o Eclesiastes, aflora em seu escrito. Junto ao livro dos Provérbios, o Eclesiastes já estava presente na Bíblia hebraica e marca a presença da sabedoria como arte de viver e como interrogação do sentido individual sem a submissão ao destino coletivo. O Eclesiastes desloca a história e se coloca frente a frente à experiência humana no que ela tem de universal. Uma lancinante abertura - "Vaidade de vaidades, tudo é vaidade" e "nada há de novo abaixo do sol" - sugere a continuidade investigativa ante um Deus incompreensível e temível (Eclesiastes, 12) sem que haja uma oração ou apelo teológico. Ele é o Criador, incognoscível.

Talvez o mais contemporâneo dos textos bíblicos, contém provérbios, aforismos, louvor, bênçãos direcionadas ao aprimoramento do leitor sem a menção aos altos feitos

\section{CANPHLAC}

Revista Eletrônica da ANPHLAC, ISSN 1679-1061, Nº. 17, p. 1-5, jul./dez. 2014. http://revista.anphlac.org.br/ 
de Israel ou à Aliança. Não cabe entrar em uma apreensão historicista da sua autoria em geral, destinada a Salomão -, mas o Eclesiastes manifesta a incerteza como condição humana. A sabedoria é um tesouro oculto, como no livro dos Provérbios, imagem a alimentar a Bíblia e que repousa na origem da parábola contada por Cristo em Mateus (13:44). O empirismo do Eclesiastes o associa ao aprimoramento por meio do discernimento das ações, como no trecho abaixo em que "Lo torcido no se puede enderezar...” (Eclesiastes 1:15).

\begin{abstract}
Me pareció oír la voz de mi padre, tal como le sonaba en los días grises de su viudez, cuando era tan dado a citar las Escrituras: «Lo torcido no se puede enderezar y lo falto no puede contarse.» Siempre andaba con esa sentencia en la boca, aplicándola en cualquier oportunidad. Y amarga me sabía ahora la prosa del Eclesiastés al pensar que el Curador, por ejemplo, se hubiera encogido de hombros ante ese trabajo mío, considerando, tal vez, que podía equipararse a trazar letras con humo en el cielo, o a provocar, con un magistral dibujo, la salivación meridiana de quien contemplara un anuncio de corruscantes hojaldres. (CARPENTIER, 1953, p. 14)
\end{abstract}

O Eclesiastes é repleto de uma sabedoria prática para obter o melhor da vida por meio da meditação nos diversos ensinamentos. O personagem principal medita na palavra, envolto na efemeridade das coisas ao seu redor. Em Los pasos perdidos, "La meditación del Eclesiastés, de los Salmos, se asociaban en su mente a inesperadas añoranzas" (CARPENTIER, 1953, p. 47). A mente do personagem principal está imersa na meditação na letra e no encontro particular de suas próprias lembranças, sem ser levado por elas. A sabedoria provém do prazer extraído das modestas alegrias da existência ante um Deus que não acolhe plenamente o desejo pelo inefável (Eclesiastes, $2: 24,3: 12,8: 15)$. No cerne da experiência de leitura dos escritos sapienciais, que sucedem as criações cosmogônicas dos onze primeiros capítulos do Gênese, está o modelo da sabedoria e o enfrentamento da morte.

Não somente a referência bíblica aos escritos sapienciais apresenta-se em seus relatos. A presença de citações do Deuteronômio é destacável. A principal delas encontra-se na abertura do romance Los pasos perdidos: "Y tu cielos que están sobre tu cabeza serán de metal; y la tierra que está debajo de ti, de hierro. Y palparás al mediodía, como palpa el ciego en la oscuridad" (Deuteronomio 28 apud

\title{
GANPHLAC
}

Revista Eletrônica da ANPHLAC, ISSN 1679-1061, №. 17, p. 1-5, jul./dez. 2014. http://revista.anphlac.org.br/ 
CARPENTIER, 1953, p. 7). Dentre um dos aspectos mais destacáveis referente à linhagem daqueles que se dedicaram a fazer uma leitura apropriativa da tradição judaico-cristã, no século XX, está a relação inextricável entre contestação e destruição de imagens. Como se observassem em seu âmago a proibição bíblica aos ídolos: "Não farás para ti ídolos [...] Não te prostrarás diante deles, nem lhes prestará cultos" (Êxodo, 20). Essa limitação não implica qualquer menosprezo ante Deus, pelo contrário, ela recusa a sua circunscrição, o que o honra e amplia para além dos limites da representação. Se, para os judeus, Deus não pode ser representado, o futuro não pode ser descrito, tão somente rascunhado por meio de parábolas e pistas.

Essa perspectiva amplia e aprofunda uma característica dos ficcionistas latinoamericanos do período (como Lezama Lima e Severo Sarduy): a dificuldade em lidar com uma noção de História linear em um esquema de progresso como categoria unitária e homogênea, ao mesmo tempo em que se diferencia de ideias substancialistas que mal dialogam com acontecimentos históricos. Se, por um lado, a relação entre legitimação histórica e legibilidade estética proporcionada pelo barroco enfatizava a melancolia ante a modernidade clássica europeia (CHIAMPI, 1998, p. 6), por outro, o bloqueio da teleologia deixava o futuro em aberto, impedindo o fechamento conclusivo manifestado em algumas propostas políticas. Apesar de presente em alguns ensaios de Carpentier, o futuro, em suas ficções históricas, não está determinado por um enredo construído sob a forma de uma comédia.

Há uma longeva tradição, fundada nos escritos judaicos, que associa a (ir)representabilidade de Deus com a preocupação com a linguagem. No século XX, como pondera Russell Jacoby, em seu livro Imagem imperfeita (2007, p. 196 - 202), essa conjunção bloqueou a representação do futuro. A fuga dos ídolos pode incluir a fuga da linguagem. A proibição de nomear Deus sustentou uma leitura, no século XX, em que a presença dos escritos judaicos antigos vinculou a busca de alguns autores no século XX (Gersom Scholem, Theodor Adorno, Walter Benjamin e Ernst Bloch) ao bloqueio da noção de futuro e à idolatria com uma voraz atenção ao presente. "Guardaivos pois de esquecer-vos da aliança que o Senhor vosso Deus fez convosco, fazendo imagens ou figuras de tudo o que o senhor vosso Deus vos proibiu" (Deuteronômio, 4). Se o limite de referência ao futuro, na obra de Alejo Carpentier, pode ser tateada por

\section{GANPHLAC}

Revista Eletrônica da ANPHLAC, ISSN 1679-1061, №. 17, p. 1-5, jul./dez. 2014. http://revista.anphlac.org.br/ 
meio de suas leituras, cabe considerar que outras associações podem ser feitas. Se a Segunda Guerra teve um impacto maior do que a Primeira Guerra na cultura mundial, como considera Hans Ulrich Gumbrecht (2013), alguns efeitos destacáveis podem ser percebidos. Além da situação de uma cultura global, há uma profunda sensação de insegurança e perigo, de motivações variadas; talvez a mais produtiva para esse texto seja a incapacidade de continuar a perceber o tempo como um agente inexorável de mudanças. Pondera que há a emergência de um novo cronotopo, após 1945, que o permite identificar o clima histórico (a Stimmung) da década imediatamente posterior à guerra por meio de topos que remetem contradições irresolutas a antigas perguntas. A situação de latência seria a expectativa, nunca alcançada, de que algo viria à tona e permitiria o escape dessa geração. Aproxima-se, dessa forma, do que aqui se tenta considerar como a ausência de um futuro esperançoso e a negação da promessa virgem da América em Los pasos perdidos, publicado nos anos seguintes à guerra.

Escrito sob a forma de um diário individual, em cada topo de um novo capítulo de Los pasos perdidos há a menção a uma passagem destacável do Antigo Testamento. O Salmo 119, salientado pela citação "Cânticos me fueron tus estutos...”, é um dos mais apreciáveis ao longo de todo o livro. Capítulo mais longo da Bíblia, composto por 22 estrofes, tendo no alfabeto hebraico a sua relação de semelhança, lembra a todo fiel a importância da palavra. A meditação na letra leva à sabedoria; sapiência permanente destinada ao aprimoramento do leitor. A sabedoria laica somente apresenta sentido quando voltada à transformação interior dada pelo refino humano apresentado em situações cotidianas e experiências práticas. Claramente expresso no Eclesiastes, o livro bíblico mais interessante, "Tudo tem o seu tempo determinado, e há tempo para todo o propósito debaixo do céu" (Eclesiastes, 3:1).

Destacável é a presença do livro de Enoque em Los pasos perdidos. Ao longo de todo o livro, suas passagens são escritas com o fito de mencionar um regresso temporal em que se aguça a solidão do criador: "Estamos en el mundo del Génesis, al fin del Cuarto Día de la creación. Si retrocediéramos un poco más, llegaríamos adonde comezara la terrible soledad del Creador" (CARPENTIER, 1953, p. 149). O encontro com uma cidade primeira relembra a cidade de Enoque: "crear y gobernar una ciudad que no figure en los mapas, que se sustraiga a los horrores de la epoca, que nasca así, de

\section{GANPHLAC}

Revista Eletrônica da ANPHLAC, ISSN 1679-1061, №. 17, p. 1-5, jul./dez. 2014. http://revista.anphlac.org.br/ 
la voluntad de un hombre... La primera ciudad. La ciudad de Henoch" (CARPENTIER, 1953 , p. 152, 156,157).

A predileção pelo livro Jó e o Eclesiastes, apontados ao longo de toda a obra, mas especialmente em Los pasos perdidos, referenciam essa escolha pelos escritos sapienciais. O livro de Jó, lido enquanto uma aposta entre Deus e Satã pelo destino dos homens, é a imagem de um narrador em sua perplexidade acerca do futuro. O livro de Jó encerra uma perspectiva dotada da autoconsciência mundana acerca da ação solitária e distante de Javé. O homem, assim como o protagonista de Los pasos perdidos, permanece sem orientação acerca de seu presente ou futuro. Em outra ênfase, o capítulo 5, intitulado "De profundis", corresponde ao Salmo 130, conhecido como o Salmo da Penitência, um salmo de esperança condizente com o "oficio del hombre" que o personagem principal de El reino de este mundo acolhe para si enquanto tarefa humana.

Iluminar os vínculos entre Alejo Carpentier e os escritos sapienciais possibilita inseri-lo em um manancial de escritores para os quais a leitura dos escritos bíblicos, em suas ficções históricas, permite captar a experiência humana em épocas diversas ao transcender os limites nacionais e ampliar a percepção daquilo que nomeamos humano. O sentido ampliado de "ficção arquivista", de González Echevarría (2000), presa aos dilemas do continente americano, pode ser relativizado por meio dessa circunscrição de um novo conjunto de leituras. A articulação entre a leitura dos escritos sapienciais e o valor da tradição, em seus ensaios e em suas ficções históricas, amplia os sentidos possíveis dados à tradição, não somente latino-americana. Carpentier lembra-nos de que estamos sempre em tradições, sem que se explicite um comportamento objetivador, de tal modo que a tradição fosse pensada como algo estranho ou alheio, posto que sempre próprio, intimidante e exemplar. Trata-se de um reconhecer-se - outra possibilidade dada à leitura dos escritos sapienciais - na qual, para o nosso juízo histórico posterior, quase já não se divisa conhecimento, mas a transformação da tradição. Carpentier, em suas ficções históricas, assim como Lezama Lima, em La expresión americana e Paradiso, operava a crítica ao historicismo (o tratamento metódico do acontecer histórico, por meio da partição sujeito/objeto), deflagrando sua ingenuidade de se deslocar ao espírito de época e pensar segundo os conceitos e representações dessa dada época. A sabedoria prática, retirada dos escritos sapienciais, nas ficções históricas de

\section{GANPHLAC}

Revista Eletrônica da ANPHLAC, ISSN 1679-1061, Nº. 17, p. 1-5, jul./dez. 2014. http://revista.anphlac.org.br/ 
Carpentier, aguça a plena percepção da distância temporal em relação aos seus estudos acerca do passado. Desse modo, a sua consciência histórica estimula a situação hermenêutica do ser histórico que somos. Essa é uma marca da nossa finitude e encontra, no caso de Carpentier, uma finalidade específica: permite-lhe criticar o caráter promissor da América radicado em um futuro esperançoso.

Por meio de suas ficções históricas, destaca que a relação com a tradição não é um saber, mas um saber-se, saber para si. A sabedoria prática presente nos escritos sapienciais e incorporada como parte de suas ficções históricas, especialmente em Los pasos perdidos, é a imagem diretriz por meio das quais seus personagens se guiam. Imagem diretriz no sentido em que Gadamer (1997, p. 472) a propõe, como aberta à alteração e vocacionada ao atuar humano como passível de receber estímulos da situação de cada momento. A partir daí, a tradição proveniente da leitura dos "Livros poéticos e sapienciais" sugere um acontecer como experiência da contingência - uma singularidade ocasional a recuperar sua fundamentação ontológica. Amplia o sentido de "ficção arquivística" ao expandir os sentidos possíveis para o que seja América, submetendo a sua designação aos dilemas da experiência humana em sua historicidade. A ênfase em uma sabedoria prática que destaca a contingência e incerteza a ampliar os sentidos do humano, seja em uma selva ou em uma Revolução no Haiti.

\section{Referências documentais e bibliográficas}

ADAMS, Michael I. Three authors of alienation; Bombal, Onetti, Carpentier. University of Texas at Austin Library, 1975.

AUERBACH, Erich. Mimesis. São Paulo: Perspectiva, 2006.

Bíblia de Jerusalém. São Paulo: Editora Paulus, 2008.

\section{CANPHLAC}

Revista Eletrônica da ANPHLAC, ISSN 1679-1061, Nº. 17, p. 1-5, jul./dez. 2014. http://revista.anphlac.org.br/ 
BIRKENMAIER, Anke. Alejo Carpentier y la cultura del surrealismo en América Latina. Madrid: Iberoamericana, 2006.

CAMUS, Albert. Essais critiques. Paris: Éditions Gallimard, 1965.

CARPENTIER, Alejo. El reino de este mundo. Santiago de Chile: Ed. Obras, 1972 [1949].

http://www.textosenlinea.com.ar/textos/El\%20reino\%20de\%20este\%20mundo.pdf

Acesso: 16/06/2014.

Diario íntimo de Kafka. In: Los pasos recobrados. Ensayos de teoria y critica literaria. Biblioteca Ayacucho, 2003. p. 45-49 [La Habana, 1951]

. "América ante la joven literatura europea" presente em Carteles, La Habana, 28/06/1931. In: Letra y Solfa. Literatura. Autores, Editorial Letras Cubanas, La Habana, 1997.

La elaboración de Ulises [1951]. In: Letra y Solfa. Literatura. Autores, Editorial Letras Cubanas, La Habana, 1997. [1958]

Guerra del tiempo: tres relatos y una novela. Madrid: Allianza Editorial, 1993.

- Los pasos perdidos. Madrid: Cátedra, 1985 [1953]. Disponível em: https://germarmu.files.wordpress.com/2014/09/alejo-carpentier-los-pasos-perdidos.pdf Acesso em: 01/03/2014.

. El siglo de las luces. Barcelona: Cátedra, 1982 [1962].

. O papel social do romancista. In: A literatura do maravilhoso. São Paulo: Edições Vértice, 1987 [1971].

- Problemática do atual romance latino-americano. In: A literatura do maravilhoso. São Paulo: Edições Vértice, 1987. [1975]

Concerto barroco. Tradução: Josely Viana Batista. São Paulo: Companhia das Letras, 2008. [1978]

CHAO, Ramón. Conversaciones con Alejo Carpentier. Madri: Literatura Alianza Editorial, 1985.

CHIAMPI, Irlemar. O realismo maravilhoso. São Paulo: Ed. Perspectiva, 1980.

Pierre Mabile e Alejo Carpentier: O surrealismo na encruzilhada do Caribe. In: PERRONE-MOISÉS, Leyla (Org.). Do positivismo à desconstrução. Ideias francesas na América. São Paulo: Iedusp, 2004.

\section{GANPHLAC}

Revista Eletrônica da ANPHLAC, ISSN 1679-1061, Nº. 17, p. 1-5, jul./dez. 2014. http://revista.anphlac.org.br/ 
Barroquismo e afasia em Alejo Carpentier. In: $O$ Barroco e a modernidade. Ensaios sobre literatura latino-americana. São Paulo: Ed. Perspectiva, 1998.

CURTIUS, Ernst Robert. Literatura europeia e idade média latina. Tradução: Teodoro Cabral. São Paulo: Ed. USP, 2013. [1948]

FELIPPE, Eduardo Ferraz. A resignação de Sísifo: tradição, cultura política e história na obra do moderno vetusto Alejo Carpentier. Tese de Doutorado em História FFLCH USP, 2013.

FOUCAULT, Michel. As palavras e as coisas. São Paulo: Ed. Martins Fontes, 1998.

História da sexualidade. O uso dos prazeres. Rio de Janeiro: Edições Graal, 1984.

1985.

História da sexualidade. O cuidado de si. Rio de Janeiro: Edições Graal,

GADAMER, Hans Georg. Verdade e método. Traços fundamentais de uma hermenêutica filosófica. Tradução: Flávio Paulo Meurer. Petrópolis, RJ: Vozes, 1997.

GAY, Peter. O estilo na história. Gibbon, Ranke, Macaulay, Burckhardt. Tradução: Denise Bottman. São Paulo: Companhia das Letras, 2006.

GILMAN, Claudia. Entre la pluma y el fusil. Debates y dilemas del escritor revolucionario en America Latina. Argentina: Siglo XXI Editores, 2003.

GONZALEZ ECHEVARRIA, Roberto. Alejo Carpentier: The Pilgrim at home. IthacaLondres: Cornell University Press, 1977. Press, 1996.

. The Cambridge history of Latin America literature. Cambridge University

(Org.). Historia y ficción en la narrativa hispanoamericana. Caracas: Monte Ávila Editores, 1984.

Mito y archivo. Una teoria de la narrativa latinoamericana. México. D.F.: Fondo de Cultura Económica, 2000.

GROTTO, Livia. Rumo ao desconhecido e originário em La vorágine de José Eustasio Rivera e Los pasos perdidos de Alejo Carpentier. Fragmentos, n. 37, p. 39-50, Florianópolis/ jul -dez/ 2009.

GUMBRECHT, Hans Ulrich. After 1945. Latency as origin of the present. Stanford University Press, 2013.

\section{CANPHLAC}

Revista Eletrônica da ANPHLAC, ISSN 1679-1061, Nº. 17, p. 1-5, jul./dez. 2014. http://revista.anphlac.org.br/ 
HANLEY, Stanley. Explosion in a Cathedral: Gnostic Archetypes in a Lukácsian Historical Novel". Mester, University of California, vol XIX, 2000. Disponível em: file:///C:/Users/efelippe/Downloads/eScholarship\%20UC\%20item\%208fg679wx.pdf

KUNDERA, Milan. A cortina: ensaio em sete partes. Tradução: Teresa Bulhões Carvalho de Fonseca. São Paulo: Companhia das Letras, 2006.

JACOBY, Russell. Imagem imperfeita. Pensamento utópico para uma época antiutópica. Rio de Janeiro: Civilização Brasileira, 2007.

LUKACS, Georg. A teoria do romance. Um ensaio histórico-filosófico sobre as formas da grande épica. São Paulo: Ed. 34, 2009.

MULER-BERG, Klaus. Asedios a Carpentier: once ensayos críticos. Chile, Ed. Universitaria, 1972.

LACAPRA, Dominick. Rethinking intellectual history: texts, contexts, language. Ithaca: Cornell University Press, 1983.

Press, 1985.

History and the novel. In: History and criticism. Ithaca: Cornell University History, politics and the novel. Ithaca, NY: Cornell University Press, 1989.

History, literature, critical theory. Ithaca: Cornell University Press, 2013.

LÓPEZ CALAHORRO, Inmaculada. Alejo Carpentier y el mundo clásico. Editorial Universidad Granada, 2006.

MOREJÓN ARNAIZ, Idalia. Política y polémica en América Latina. México: Ediciones de Educación y Cultura, 2010.

PALMERO GONZÁLEZ, Elena (Org.). No reino de Alejo Carpentier: doze ensaios críticos. Rio Grande: Editora FURG, 2009.

PADURA FUENTES, Leonardo. Un camino de medio siglo: Alejo Carpentier y la narrativa de lo real maravilloso. Mexico: Fondo de Cultura Economica, 2002.

RODRIGUES DA SILVA, Helenice. O mito da revolução no imaginário político dos intelectuais de esquerda francesa (1950-1980). In: Fragmentos da história intelectual. Entre questionamentos e perspectivas. Campinas, SP: Papirus, 2002.

SELLIER, Philippe. Para conhecer a bíblia. Um guia histórico e cultural. Tradução: Dorothée de Bruchard. São Paulo: Martins Fontes, 2011.

\section{CANPHLAC}

Revista Eletrônica da ANPHLAC, ISSN 1679-1061, No. 17, p. 1-5, jul./dez. 2014. http://revista.anphlac.org.br/ 
WHITE, Hayden. La política de la interpretación histórica. In: El contenido de la forma. Paidós: Barcelona, 1992.

Historical fiction, fictional history and historical reality. Rethinking history, v. 9, n. 2/3, June/September, 2005, p. 147-157.

ZALDÍVAR, Francisco Ernesto Zaragoza. La crítica de la modernidad en Grande Sertão: Veredas y Los pasos perdidos. Tese de Doutorado em Literatura Espanhola e Hispano-americana. São Paulo: USP, 2005.

\section{GANPHLAC}

Revista Eletrônica da ANPHLAC, ISSN 1679-1061, №. 17, p. 1-5, jul./dez. 2014. http://revista.anphlac.org.br/ 